\title{
USO DE NOVAS TECNOLOGIAS PARA A INOVAÇÃO DIDÁTICA NO ENSINO DE MATEMÁTICA E CIÊNCIAS
}

\author{
Renan Barros da Silva ${ }^{1}$ \\ Herbert Gomes Martins ${ }^{2}$
}

Resumo: O Programa de Pós-graduação em Ensino das Ciências - PPGEC, da UNIGRANRIO, mantém um mestrado profissional frequentado por professores em exercício na educação básica. Haveria uma contribuição originária dessa produção discente para a inovação didática no ensino de ciências e matemática? Para responder a essa indagação, optou-se por identificar a contribuição nas dissertações defendias no quadriênio 2012-2015 que tenham como objetivo a melhoria do ensino e aprendizagem nesse campo, na perspectiva de uma nova atitude do aluno e do professor frente ao processo educacional. $O$ critério principal de seleção das dissertações é o uso de novas tecnologias para o ensino e aprendizagem de matemática e ciências. Espera-se que, após o levantamento e análise da produção existente no período delineado, seja possível relacionar as inovações didáticas e suas aplicações no ensino, com a disponibilização de material em banco virtual como produto tecnológico da pesquisa.

Palavras-chave: ensino de ciências; matemática; didática; aprendizagem.

\footnotetext{
1 Sistemas de Informação/ UNIGRANRIO, Brasil. renanbarrosrbs@gmail.com.

2 Engenharia de Produção/ UNIGRANRIO, Brasil. hmartins@unigranrio.edu.br.
} 